\title{
BMI Assessment Machine with Recommended Ideal Weight
}

\author{
Ertie C. Abana, Ceferino Llamelo, Thom Benedict Daña, Reymundo III Cafugauan, Nicole Angelo \\ Malpaya, Adrianne Cleto Maramag \\ Computer Engineering Program, School of Engineering, Architecture and Information Technology Education, \\ University of Saint Louis, Tuguegarao City, Cagayan, Philippines, \\ ertie04@gmail.com
}

\begin{abstract}
Awareness of Body Mass Index (BMI) can be the guide to adjust a person's lifestyle and maintain a normal healthy body. This study developed a BMI assessment machine that automatically calculates BMI value, displays the nutritional status and suggests ideal weight. The machine is composed of a microcontroller that interconnects the other components of the machine which includes load cell that gets the weight, an ultrasonic sensor that gets the height, keypad as the input mechanism and Liquid Crystal Display (LCD) as the display mechanism. The machine is very useful most especially to children in such a way that as young as their age they are already aware of their nutritional status. In the several testing that was conducted, the BMI machine was highly accurate in determining BMI. The suggestion of ideal weight by the machine was comparable to the manual calculation of ideal weight.
\end{abstract}

Key words: body mass index, microcontroller, load cell, ultrasonic sensor.

\section{INTRODUCTION}

Each year Filipinos celebrate fiestas in every city and barrio in the Philippines. Gatherings are also held by the majority of the Filipino families, but what is common during these events is the food that is being laid on the table. Filipinos are essentially imbued with the utmost desire for food but not aware of the food that contains high cholesterol causing a high amount of body fats which can lead to weight-related diseases. In the 2014 Global Status Report on Non-communicable diseases (NCDs) by the World Health Organization, out of the 16 million premature deaths, $82 \%$ are associated with NCDs that occur in low and middle countries. In the Philippines alone, 57\% of total deaths were due to cancer, cardiovascular disease, diabetes, and chronic respiratory disease. In which among Filipino adults, 27\% are overweight and obese, $25 \%$ have hypertension, $5 \%$ have high blood sugar and $10 \%$ have high total cholesterol levels in the current prevalence of NCD risk factors. The number of obese and overweight children and adolescents has also been on the rise in the Philippines and the rest of the world over the last decade. The 8th national nutrition survey shows that among Filipino children of age zero to five, the prevalence of overweight has significantly increased from 1\% in 1989 to $5 \%$ in 2013. On the other hand, the prevalence of overweight Filipino children of age five to ten was 5.8\% in 2003 and leaped to $9.1 \%$ in 2013. Awareness of BMI testing from childhood and adulthood can help maintain normal body weight to lessen the risk of having NCD diseases. In fact, a fellow in the Division of Endocrinology at Cincinnati Children's Hospital Medical Center said that BMI level measurement predicts obesity risk.

There are lots of health-related technologies that can measure Body Mass Index (BMI). These include BMI calculator software [1], [2], handheld devices [3]-[5], and BMI Machines [6], [7]. The BMI calculator software requires weight and height to be inputted in order to distinguish if a person is normal, overweight, underweight or obese. The handheld devices that calculate BMI value also requires the user to manually input their weight and height. On the other hand, BMI machines automatically display the height, weight and calculated BMI value. The BMI machine gets the weight and height through a load cell and an ultrasonic sensor, respectively. The height and weight are processed by a microcontroller and the result is shown in the LCD. These technologies used BMI formulas to compute the BMI level of each individual but only usable for adults over 20 years old.

Considering that there is an increasing number of children that are obese and overweight, a BMI assessment machine that automatically calculates the BMI level of an individual age 2 and above was developed. It has a unique feature where the BMI category and ideal weight of the user is displayed so that they will be aware of their nutritional status and have a target weight which is something that no other machine is capable of doing. This study will give a great boost in the health sector particularly hospitals, clinics, and barangay health centers for the gathering of BMI that determine underweight, overweight and normal which can be used for the Feeding Program, normal BMI maintenance, and 
Ertie C. Abana et al., International Journal of Advanced Trends in Computer Science and Engineering, 9(3), May - June 2020, 4163 -4167

statistical analysis. It will also help those who are health conscious to easily monitor their healthy body. The information from the machine is not intended to substitute professional health care but rather help them in determining their patient's nutritional status.

\section{MATERIALS AND METHODS}

The block diagram in Figure 1 shows the interconnection of the different components of the BMI Assessment machine that includes a microcontroller, ultrasonic sensor, keypad, load cell with load cell amplifier and liquid crystal display. The open-source [8-9] Arduino microcontroller is a general-purpose microcontroller [10-11]. It is responsible for the overall operation of the machine. The input device of the machine comprises of the keypad, ultrasonic sensor, and load cell. The keypad acts as the input mechanism for the data that will be coming from the user. The ultrasonic sensor serves as the height sensor while the load cell with load cell amplifier acts as the weight sensor. After the inputs are processed by the microcontroller, it is being displayed with a user-centered design [12] in the liquid crystal display (LCD).

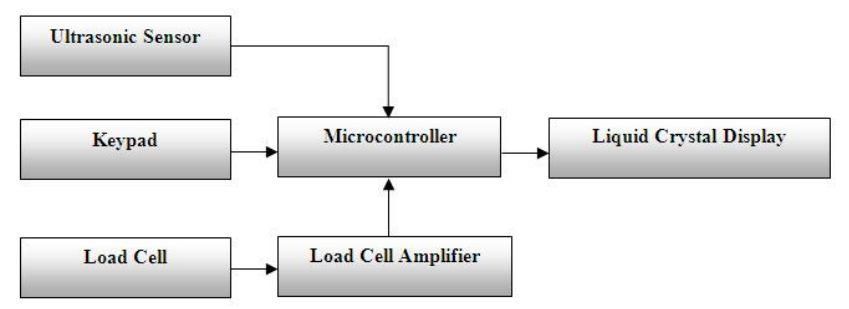

Figure 1: Block Diagram of the BMI Machine

\subsection{Project Development}

The schematic diagram of the BMI machine is presented in Figure 2. The components which serve as inputs for the machine are the load cell, ultrasonic sensor, and keypad. The load cell is capable of converting pressure (force) into an electrical signal. This signal is read and amplified by the HX711, a load cell amplifier. The load cell is connected to the HX711 input side while the output side of the HX711 is connected to the Arduino. The pins 1, 2, 3, 4, 5, 6, 7, 8 of the keypad are connected to the digital pins 8, 9, 10, 11, 4, 5, 6, 7 of the Arduino, respectively. Lastly, the trigger pin (input) and echo pin (output) of the ultrasonic sensor is connected to the digital pin 13 and pin 12 of the Arduino, respectively. The output is shown in the 4x20 I2C Liquid Crystal Display. The SDA and SCL pins of the LCD are connected to the SDA and SCL pins of the microcontroller. The machine has a common $\mathrm{VCC}$ and ground.

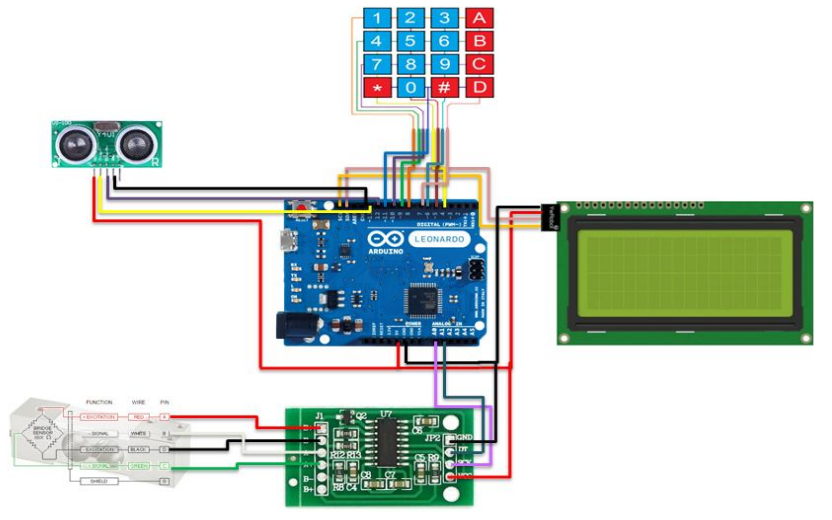

Figure 2: Schematic Diagram of the BMI Machine

\subsection{Computation of BMI}

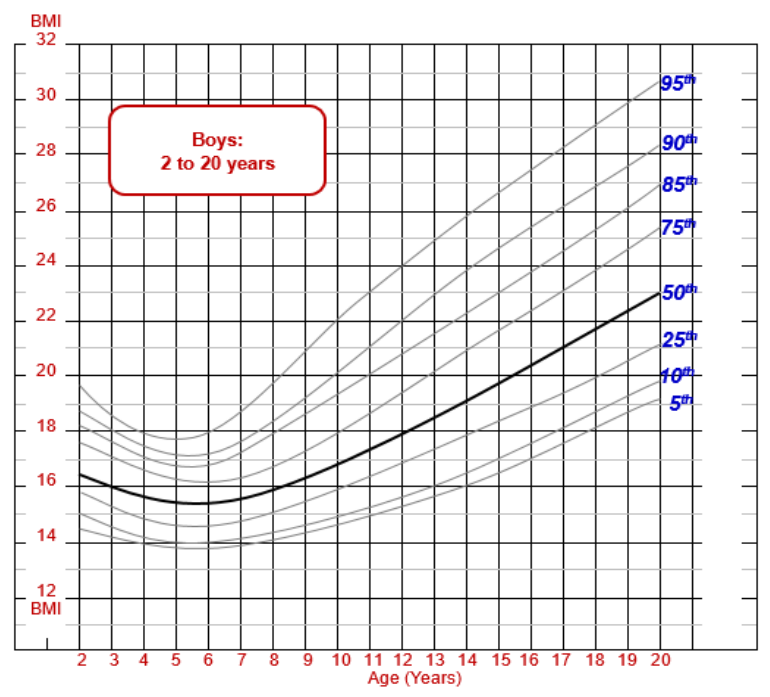

Figure 3: Growth Chart for Boys from CDC

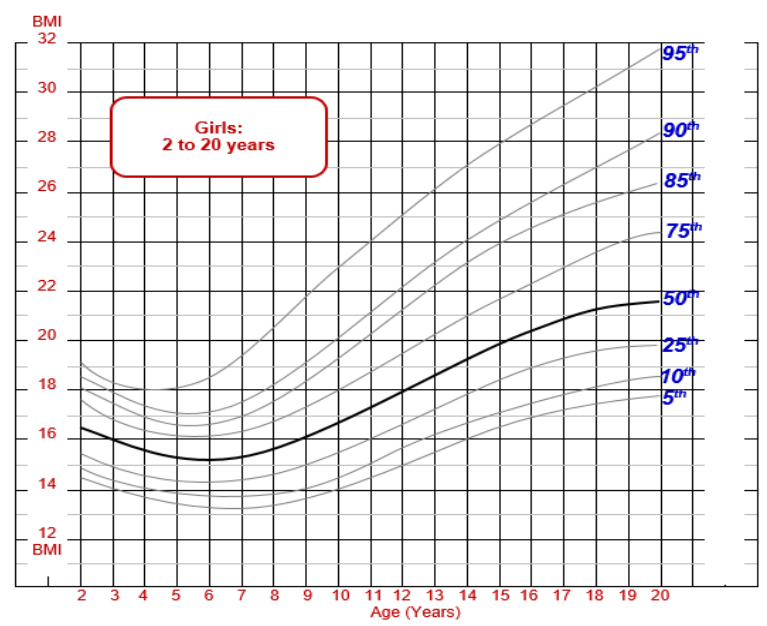

Figure 4: Growth Chart for Girls from CDC

Figure 3 and Figure 4 show the growth chart that happens in boys and girls age 2 to 20 years. Table 1 shows that for 2 to 20 years old males and females if the computed BMI is above 85th percentile it is classified as overweight. Anything that falls into 5th -85 th is classified as normal and less than 5th percentile is underweight. 
Ertie C. Abana et al., International Journal of Advanced Trends in Computer Science and Engineering, 9(3), May - June 2020, 4163 -4167

There is a distinct range for every BMI categories such as underweight, normal, overweight and obese as shown in Table 2. One of these categories is shown in the LCD module based on the computed BMI by the machine.

Table 1: Classification of BMI for Age 2 - 20 Years Old

\begin{tabular}{|c|c|}
\hline Category & Range \\
\hline Overweight & $>85^{\text {th }}$ \\
\hline Normal & $5^{\text {th }}-85^{\text {th }}$ \\
\hline Underweight & $<5^{\text {th }}$ \\
\hline
\end{tabular}

The BMI (1) is the value of mass in kilograms divided by the value of height squared in meters. It is used as a value to classify whether a person is underweight, normal, overweight or obese. It was also used to determine the BMI value of individuals. The machine that is developed uses the SI units in computing the BMI for it is widely used in the Philippines.

Table 2: Classification of BMI for 20 and above

\begin{tabular}{|c|c|}
\hline Category & BMI Range \\
\hline Underweight & 18.49 and below \\
\hline Normal & $18.5-24.99$ \\
\hline Overweight & $25-29.99$ \\
\hline Obese Class & 30 and above \\
\hline
\end{tabular}

$$
B M I=\operatorname{mass}(k g) / h e i g h t^{2}(m)
$$

\subsection{Ideal Weight Range}

The ideal weight range is the product of the normal BMI range and the height squared in meters. It is used to identify the target weight of the individuals for guidance with respect to nutritional status.

\subsection{Ideal Weight Range}

The percent error formula is a useful tool to determine the precision of the calculations of BMI value. The formula (2) is given by the measured value (MV) that is the actual value and the theoretical value (TV) as the expected value. Subtracting the value from 100 will give the percent accuracy.

$$
\% \text { Accuracy }=100-\left|\frac{\mathrm{TV}-\mathrm{MV}}{\mathrm{TV}}\right| \times 100 \%
$$

\subsection{Success Rate}

Success rate (3) is the most common and easy to understand the way of measuring the ability of the machine to complete a task. It used to interpret the success rate of the BMI machine in classifying the nutritional status and ideal weight. The success rate is the ratio of the number of success attempts (NSA) to the total number of attempts (TNA) multiplied by 100.

$$
\text { Success Rate }=\frac{N S A}{T N A} \times 100 \%
$$

\section{RESULTS AND DISCUSSION}

Several testing was conducted at the University of St. Louis Tuguegarao clinic with the working prototype of the BMI machine as shown in Figure 5.

The machine automatically calculates the Body Mass Index and displays the nutritional status and ideal weight on the LCD. It is tolerably reliable and precise in terms of getting the height and weight of a subject. Portability is one of the good features of the machine. Having a portable machine with a replaceable battery for medical missions can be taken anywhere. Furthermore, the machine is easy and safe to use. The Arduino board enables the machine to process and display the output faster than a PIC microcontroller that was used in a previous study [13]. A height stand that can be adjusted was implemented in the BMI machine that was not integrated into the previous studies [6], [7].

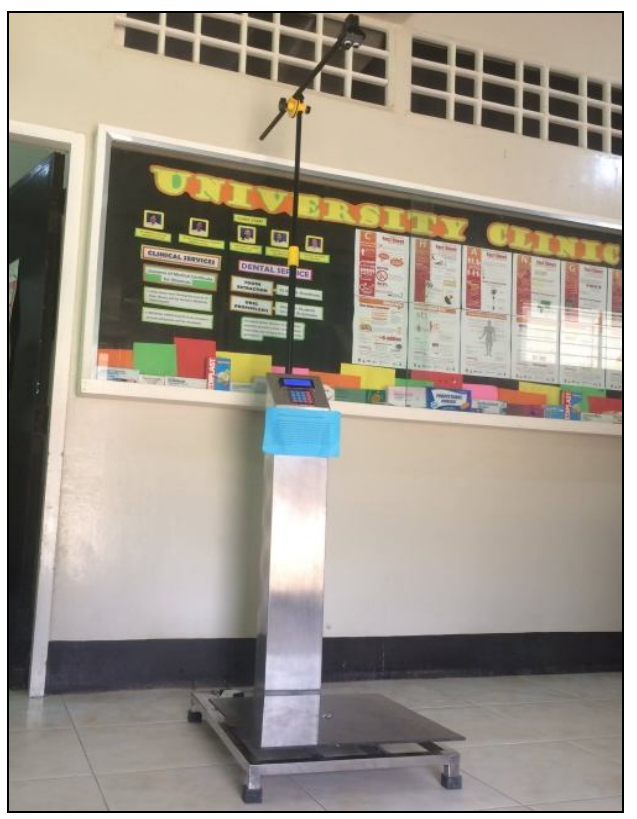

Figure 5: The working prototype of the BMI Machine

\subsection{Testing of BMI Calculation}

There were twenty-two (22) random individuals ages 4 and above that was selected to use the machine under the supervision of the university nurse and doctor. During the testing, the weight and height of every individual were manually measured and recorded. After the manual measurement, the individuals are asked to use the machine.

\begin{tabular}{|c|c|c|c|c|c|c|c|c|c|}
\hline \multirow[b]{2}{*}{ Trial } & \multirow[b]{2}{*}{ Age } & \multirow[b]{2}{*}{ Gender } & \multicolumn{3}{|c|}{ Expected } & \multicolumn{3}{|c|}{ Actual } & \multirow[b]{2}{*}{$\begin{array}{c}\% \\
\text { Accuracy }\end{array}$} \\
\hline & & & $\begin{array}{l}\text { Ht. } \\
\text { (cm) }\end{array}$ & $\begin{array}{l}\text { Wt. } \\
\text { (kg) }\end{array}$ & BMI & $\begin{array}{l}\text { Ht. } \\
\text { (cm) }\end{array}$ & $\begin{array}{l}\text { Wt. } \\
\text { (kg) }\end{array}$ & BMI & \\
\hline 1 & 4 & F & 99 & 14.50 & 14.79 & 97 & 15.15 & 16.10 & 91.14 \\
\hline 2 & 4 & $M$ & 111 & 41.50 & 33.68 & 110 & 41.09 & 33.96 & 99.17 \\
\hline 3 & 5 & $\mathrm{M}$ & 103 & 14.60 & 13.76 & 102 & 14.79 & 14.22 & 96.66 \\
\hline 4 & 6 & $\mathrm{~F}$ & 115 & 29.40 & 22.23 & 118 & 29.85 & 21.44 & 96.45 \\
\hline
\end{tabular}
The data gathered are given in Table 3.

Table 3: Calculated BMI value of the Machine 
Ertie C. Abana et al., International Journal of Advanced Trends in Computer Science and Engineering, 9(3), May - June 2020, 4163 -4167

\begin{tabular}{|c|c|c|c|c|c|c|c|c|c|}
\hline 5 & 6 & $\mathrm{M}$ & 114 & 18.51 & 14.24 & 112 & 18.57 & 14.80 & 96.07 \\
\hline 6 & 8 & $\mathrm{~F}$ & 131 & 49.60 & 28.90 & 130 & 49.52 & 29.30 & 98.62 \\
\hline 7 & 7 & $\mathrm{~F}$ & 117 & 26.90 & 19.65 & 117 & 26.83 & 19.60 & 99.75 \\
\hline 8 & 7 & $\mathrm{~F}$ & 131 & 43.11 & 25.12 & 130 & 43.10 & 25.50 & 98.49 \\
\hline 9 & 8 & $\mathrm{M}$ & 134 & 51.00 & 28.40 & 132 & 51.05 & 29.30 & 96.83 \\
\hline 10 & 7 & $\mathrm{M}$ & 115 & 20.50 & 15.50 & 117 & 20.67 & 15.10 & 97.42 \\
\hline 11 & 11 & $\mathrm{~F}$ & 140 & 40.94 & 20.89 & 140 & 41.51 & 21.18 & 98.61 \\
\hline 12 & 9 & $\mathrm{~F}$ & 118 & 19.80 & 14.22 & 117 & 19.44 & 14.20 & 99.86 \\
\hline 13 & 11 & $\mathrm{M}$ & 140 & 34.01 & 17.35 & 141 & 34.39 & 17.30 & 99.71 \\
\hline 14 & 10 & $\mathrm{~F}$ & 131 & 28.50 & 16.61 & 132 & 28.51 & 16.36 & 98.49 \\
\hline 15 & 9 & $\mathrm{~F}$ & 126 & 31.59 & 19.90 & 126 & 31.59 & 19.90 & 100.00 \\
\hline 16 & 9 & $\mathrm{M}$ & 130 & 36.71 & 21.72 & 131 & 36.72 & 21.40 & 98.53 \\
\hline 17 & 12 & $\mathrm{M}$ & 156 & 59.77 & 24.56 & 156 & 59.43 & 24.42 & 99.43 \\
\hline 18 & 18 & $\mathrm{~F}$ & 158 & 50.43 & 20.20 & 158 & 50.18 & 20.10 & 99.50 \\
\hline 19 & 18 & $\mathrm{~F}$ & 153 & 54.78 & 23.40 & 152 & 54.06 & 23.40 & 100.00 \\
\hline 20 & 20 & $\mathrm{M}$ & 180 & 62.69 & 19.35 & 180 & 62.69 & 19.35 & 100.00 \\
\hline 21 & 36 & $\mathrm{M}$ & 149 & 50.84 & 22.90 & 149 & 51.57 & 23.23 & 98.56 \\
\hline 22 & 21 & $\mathrm{M}$ & 162 & 83.59 & 31.85 & 162 & 83.74 & 31.91 & 99.81 \\
\hline
\end{tabular}

The expected BMI values are based on manual calculation while the actual BMI values are calculated by the machine. The manual calculation was done using a calculator wherein the formula for BMI (1) was used. The percent accuracy was calculated using the percent accuracy formula (2). According to the university doctor, BMI values from expected and actual with a minimal deviation are negligible. Out of the 22 random individuals, the average percent accuracy of the machine in getting the BMI value was $98.32 \%$ which is higher than the previous study [6].

The BMI machine is capable of computing the BMI value of age 20 and below unlike previous studies [6], [7] that can only be used for individuals age 20 and above.

\subsection{Testing of Nutritional Status Classification}

Another output from the BMI machine when the 22 individuals used it was the nutritional status. The nutritional status displayed in the BMI machine was compared to the nutritional status that can be derived using a BMI calculator device used in the university clinic.

Table 4: Classified Nutritional Status of the Machine

\begin{tabular}{|c|c|c|c|c|}
\hline Trial & BMI & $\begin{array}{c}\text { Expected } \\
\text { Nutritional } \\
\text { Status }\end{array}$ & $\begin{array}{c}\text { Actual } \\
\text { Nutritional } \\
\text { Status }\end{array}$ & Results \\
\hline 1 & 14.79 & Normal & Normal & Correct \\
\hline 2 & 33.68 & Overweight & Overweight & Correct \\
\hline 3 & 13.76 & Normal & Normal & Correct \\
\hline 4 & 22.23 & Overweight & Overweight & Correct \\
\hline 5 & 14.24 & Normal & Normal & Correct \\
\hline 6 & 28.90 & Overweight & Overweight & Correct \\
\hline 7 & 19.65 & Normal & Normal & Correct \\
\hline 8 & 25.12 & Overweight & Overweight & Correct \\
\hline 9 & 28.40 & Overweight & Overweight & Correct \\
\hline 10 & 15.50 & Normal & Normal & Correct \\
\hline 11 & 20.89 & Normal & Normal & Correct \\
\hline 12 & 14.22 & Normal & Normal & Correct \\
\hline 13 & 17.35 & Normal & Normal & Correct \\
\hline 14 & 16.61 & Normal & Normal & Correct \\
\hline 15 & 19.90 & Normal & Normal & Correct \\
\hline 16 & 21.72 & Normal & Normal & Correct \\
\hline 17 & 24.56 & Overweight & Overweight & Correct \\
\hline 18 & 20.20 & Normal & Normal & Correct \\
\hline
\end{tabular}

\begin{tabular}{|c|c|c|c|c|}
\hline 19 & 23.40 & Normal & Normal & Correct \\
\hline 20 & 19.35 & Normal & Normal & Correct \\
\hline 21 & 22.90 & Normal & Normal & Correct \\
\hline 22 & 31.85 & Obese & Obese & Correct \\
\hline
\end{tabular}

The BMI machine has a $100 \%$ success rate in classifying the BMI as shown in Table 4. This is way better compared to a previous study [6] that only acquired an $80 \%$ success rate in classifying their BMI value.

\subsection{Testing of Ideal Weight Range}

Table 4 shows the suggested ideal weight of the BMI machine using the ideal weight formula. From the 22 individuals, only one resulted in incorrect suggestions.

Table 5: Calculated Ideal Weight Range of the Machine

\begin{tabular}{|c|c|c|c|c|c|}
\hline Trial & $\begin{array}{c}\text { Height } \\
(\mathbf{c m})\end{array}$ & $\begin{array}{c}\text { Normal } \\
\text { BMI } \\
\text { Range }\end{array}$ & $\begin{array}{c}\text { Expected } \\
\text { Ideal Weight } \\
(\mathbf{k g})\end{array}$ & $\begin{array}{c}\text { Actual Ideal } \\
\text { Weight (kg) }\end{array}$ & Results \\
\hline 1 & 99 & $13-18$ & $12.70-17.60$ & $13.00-17.00$ & Correct \\
\hline 2 & 111 & $14-17$ & $17.20-20.90$ & $17.00-21.00$ & Correct \\
\hline 3 & 103 & $13-17$ & $13.80-18.03$ & $14.00-18.00$ & Correct \\
\hline 4 & 115 & $13-18$ & $17.20-23.80$ & $19.00-26.00$ & Incorrect \\
\hline 5 & 114 & $13-18$ & $16.90-23.40$ & $17.00-23.00$ & Correct \\
\hline 6 & 131 & $13-20$ & $22.30-34.30$ & $22.00-34.00$ & Correct \\
\hline 7 & 117 & $13-19$ & $17.80-26$ & $18.00-27.00$ & Correct \\
\hline 8 & 131 & $13-19$ & $22.30-32.60$ & $22.00-33.00$ & Correct \\
\hline 9 & 134 & $13-20$ & $23.30-35.90$ & $23.00-35.00$ & Correct \\
\hline 10 & 115 & $13-19$ & $17.20-25.10$ & $18.00-27.00$ & Correct \\
\hline 11 & 140 & $14-24$ & $27.40-47$ & $28.00-48.00$ & Correct \\
\hline 12 & 118 & $13-21$ & $18.10-29.20$ & $18.00-29.00$ & Correct \\
\hline 13 & 140 & $14-23$ & $27.40-45$ & $28.00-46.00$ & Correct \\
\hline 14 & 131 & $14-22$ & $24-37.80$ & $25.00-39.00$ & Correct \\
\hline 15 & 126 & $13-21$ & $20.60-33.30$ & $21.00-34.00$ & Correct \\
\hline 16 & 130 & $13-21$ & $22-35.50$ & $23.00-37.00$ & Correct \\
\hline 17 & 156 & $14-24$ & $34-58.40$ & $35.00-59.00$ & Correct \\
\hline 18 & 158 & $17-30$ & $42.40-74.90$ & $43.00-75.00$ & Correct \\
\hline 19 & 153 & $17-30$ & $39.80-70.20$ & $40.00-70.00$ & Correct \\
\hline 20 & 180 & $19-30$ & $61.60-97.20$ & $62.00-97.00$ & Correct \\
\hline 21 & 149 & $18-25$ & $40-55.50$ & $40.00-56.00$ & Correct \\
\hline 22 & 162 & $18-25$ & $47.20-65.60$ & $48.00-66.00$ & Correct \\
\hline
\end{tabular}

The normal BMI range differs by age and gender. The given normal BMI range was based on the CDC growth chart for boys and girls. The expected ideal weight and actual ideal weight may differ if the height measured by manual measurement is not the same as the height detected by the BMI machine. The actual ideal weight gathered has \pm 1 tolerance. The data in Table 5 reveals that the expected and actual ideal weight has a minimal deviation with one incorrect suggestion that has exceeded the tolerance. Using the success rate formula (3), the BMI machine achieved a $95.45 \%$ success rate in suggesting the correct ideal weight for the 22 individuals. The calculation of ideal weight by the BMI machine makes it unique from the previous machines [1-7] that were not able to include this feature which is intended to show the person's target weight. 


\section{CONCLUSION}

The BMI assessment machine was able to display the height, weight, BMI, nutritional status and ideal weight range. The results revealed that the computed BMI had a minimal deviation from the expected and actual value that was negligible but since the nutritional status was on a range basis in classifying BMI, the individual who uses the machine still fall on the correct weight category. The same was true in the ideal weight range wherein a very high success rate was achieved.

\section{REFERENCES}

1. G. Ross, Y. Ben-zvi, and S. Merritt. Systems and methods for automated body mass index calculation to determine value. U.S. Patent 9,839,376, December $12,2017$.

2. R. Maljanian. System and method for analyzing body mass. U.S. Patent 11/732,760, February 28, 2008.

3. T. Hazzard. Writing pen that calculates body mass index. U.S. Patent 6,890,117, May 10, 2005.

4. V. Averbach. BMI Ruler. U.S. Patent 11/689,413, September 25, 2008.

5. J. Holland. Body mass index calculator. U.S. Patent 29/193,578, February 15, 2005.

6. B. M. S. Baladad, J. Magsombol, J. N. Roxas, E. De Castro, and J. Dolot, Development of Automated Body Mass Index Calculation Device. International Journal of Applied Engineering Research vol. 11, no. 7, pp. 5195-5201, 2016.

7. B. U. Ismail, S. F. Akbar Ali, and A. A. Ayaz. Microcontroller Based Automated Body Mass Index (BMI) Calculator with LCD Display. In 2nd International Conference on Electrical, Electronics and Civil Engineering, Singapore, pp. 28-29, April, 2012.

8. I. M. Supriyono and W. Adi Siswanto. The Development of Engine Control Module Manipulator Module Based on Arduino to Increase Power and Torque of Motorcycle Engine. International Journal of Advanced Trends in Computer Science and Engineering (IJATCSE), vol. 8, no. 6, pp. 3135-3139, 2019.

https://doi.org/10.30534/ijatcse/2019/76862019

9. L. Bulan, L. Maderazo and P. Asi. Design and Development of Microcontroller-based Air Conditioning Units Controller as Input to Energy Conservation for University of Batangas. International Journal of Advanced Trends in Computer Science and Engineering (IJATCSE), vol. 8, no. 4, pp. 1020 - 1025, 2019.

https://doi.org/10.30534/ijatcse/2019/06842019

10. E. Abana, C. V. Dayag, V. M. Valencia, P. Talosig, J. P. Ratilla, \& G. Galat. Road flood warning system with information dissemination via social media. International Journal of Electrical \& Computer Engineering, vol. 9 no. 6, part 1, pp. 4979-498, 2019. https://doi.org/10.11591/ijece.v9i6.pp4979-4987
11. E. Abana, T. B. Daña, C. Alan, J. M. Martin, R. Buraga, and C. Balagtas. Self-Service Checkout System for Groceries. International Journal of Recent Technology and Engineering, vol. 8, no. 4, pp. 1816-1818, 2019.

12. E. Abana. Usability of "Traysi": A Web Application for Tricycle Commuters. International Journal of Advanced Computer Science and Applications, vol. 10, no. 7, pp. 280-284, 2019. https://doi.org/10.14569/IJACSA.2019.0100738

13. D. S. Varma, S. Dipika, V. Mhatre, P. More, and S. S. Ayane. Measurement of Body Mass Index (BMI) using PIC 18F452 Microcontroller, International Journal on Recent and Innovation Trends in Computing and Communication, vol. 3, pp. 2213-2216, 2015. https://doi.org/10.17762/ijritcc2321-8169.150497 